\title{
前方後方押出しによる複合ギア成形* (成形性と金型応力に及ぼすスラグ形状の影響)
}

\author{
佐 藤 征 亚*1, 木之下 広幸*2, 外山真 也*3 \\ 河野通 成 ${ }^{* 4}$, 平田幸 次 ${ }^{* 4}$, 海 津 浩 - *5

\section{Compound Gear Forming by Forward-Backward Extrusion (Influence of Slug Shape on Formability and Die Stress)}

\author{
Masatsugu SATO ${ }^{* 6}$, Hiroyuki KINOSHITA, Masaya TOYAMA, \\ Michinari KAWANO, Koji HIRATA and Koichi KAIZU \\ *6 Miyazaki Prefecture Mechanical Technology Center, \\ 39-82 Ootakecho, Nobeoka-shi, Miyazaki, 882-0024 Japan
}

\begin{abstract}
The compound gear has a gear on one side and a cam profile on the other side. It is used in a seat belt system for an automobile. The compound gear has been produced through multiple forging processes and cutting processes. From the requirement for the lower costs of production and labor saving, it is very important to reduce the number of forging processes. So, the compound gear forming by the forward-backward extrusion in the cold forging was attempted. But it is very difficult to obtain the product without the defect, and the damage of the die sometimes occurs. In this study, to obtain the suitable slug shape for improving formability of the slug and preventing the damage of the die, 3D finite element simulations for the forward-backward extrution process using several types of slugs with the different shapes in cross section and the same volume were carried out, and the relationship between the slug shape and its formability and the influence of the slug shape on the stress of the die in the extrusion process were examined in detail. On basis of the obtained results, the suitable slug shape which was able to be formed into near net shape of the product and which could be formed in the lower extrusion load were proposed. The effects of the proposed slug shape on the forward-backward extrusion in the cold forging were also confirmed by the finite element simulation and the experiment.
\end{abstract}

Key Words : Forging, Extruding, Plastic Working, Gear, Formability, Metal Flow, Die Stress, Finite Element Method

1.

複合ギアは自動車用シートベルトに用いられてい る部品で, 図 1 に示すように, カムとギアの両形状を 有する複雑な形状をしている．複合ギアの素材には機 械構造用炭素鋼鋼材（S15C 材またはAISI-4140 材）が 用いられ，従来から複数の泠間鍛造工程を経た後に切 削加工を行うことにより作製されている. しかし，複 数の鍛造工程を経ることにより形状誤差が累積すると いう問題があり，その誤差を除去するためには高精度 の切削加工が必要な上に多量の切りくずも生じてい た. さらに近年の厳しいコスト削減の要求から, 鍛造

* 原稿受付 2010 年 6 月 4 日.

*1 宮崎県機械技術センター( $882-0024$ 延岡市大武町 39-82).

*2 正員, 宮崎大学工学部 (- 889-2192 宮崎市学園木花台西 11).

*3 正員, 宮崎県工業技術センター(ङ 880-0303 宮崎市佐土原 町東上那珂 $16500-2)$.

*4 (株)二チワ(㤲 889-3151 日南市上方 1765).

*5 正員, 兵庫県立大学大学院工学研究科 (牢 671-2280 姫路市 書写 2167).

E-mail : sato@mmtc.or.jp
工程数を可能な限り削減することによる生産の効率化 が強く求められている. そこで我々は，一工程の冷間， 鍛造で不具合のない製品形状を得ることを目標とし
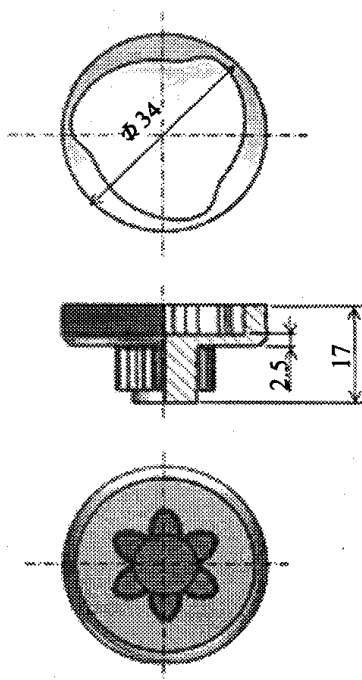

Fig. 1 Schematic illustration of compound gear 
て，冷間での前方後方押出しによる複合ギアのニアネ ットシェイプ成形を試みた.

これまでに冷間での前方後方押出しによる成形で は，素材の流動応力（変形抵抗）が非常に高くなるた めに成形性が悪く，製品に何らかの欠陥が発生するこ とが多いと報告されている ${ }^{(1)}$ ，我々も一定断面を有 する形状のスラグを用いて，冷間での前方後方押出し により複合ギアの成形を試みた．図 2 は，その成形品 に生じた欠陷と金型の損傷状況の一例を示している. この図から，ギア部の先端には欠肉による未充填部分 が生じ，歯先部にはき裂が生じている．また，カム部 のフランジにはフローマークが発生している.さらに, 金型表面には割れや剥離などが生じている。したがっ て，これらの不具合を改善する何らかの手段を講じな ければならないが, これまでに本研究で対象とするよ うな歯形を有する複雑形状の部品を冷間前方後方押出 しにより良好な状態に成形する指針は示されていない ようである，そのような状況の中で，過去のかさ歯車 の鍛造に関する研究 ${ }^{(2)} \sim\left({ }^{4}\right)$ において, 歯部一の材料 の充填は中実円柱形状のスラグの直径と高さにようて 影響を受けることから，歯先に欠肉などの欠陥を生じ させないためには，適切な形状の円柱状スラグを選ぶ 必要があることが報告されている：しかしながら，こ れらの報告では，スラグの形状は中実円柱形状に限定
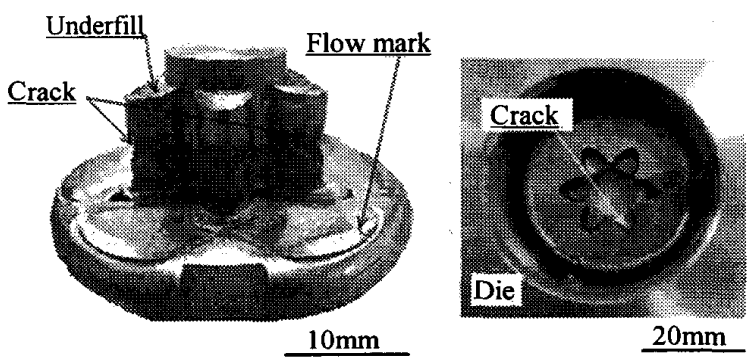

Fig. 2 Some defects of the product and damage of die

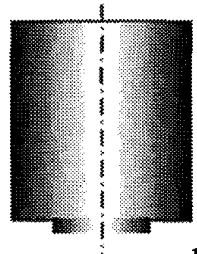

(A) T-1

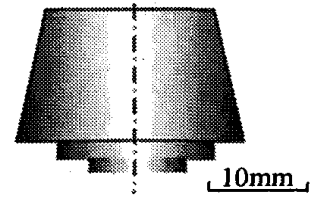

(C) T-3

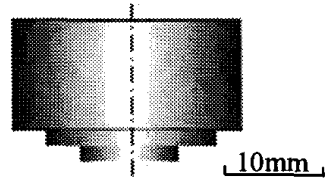

(B) T-2

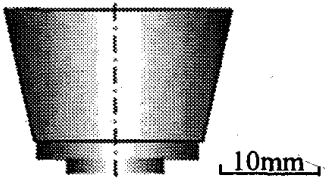

(D) T-4
Fig. 3 Various shapes of slugs used for experiments and numerical simulations
されており，複合ギアのような複雑な形状の製品を前 方後方押出しにより成形する場合に，このような単純 な形状が適切な形状であるかは不明である.

本研究では，複合ギアの泠間前方後方押出しにおけ る不具合を改善する手段として，変断面形状を有する スラグを用いる．これによって，材料の塑性流れを制 御し, 複合ギアのニアネットシェイプ成形が実現でき るとともに，金型への負荷の低減も同時に実現できる ことを示す.

具体的には，本研究においては，実材料を用いた実 機による試行錯誤的な成形トライは金型が破損する可 能性が高いので実施できない，そのため，まず適切な スラグ形状を決定するための知見を得るために，一定 体積で断面積の異なる数種類のスラグ形状を用いて, 三次元有限要素法によるスラグの成形解析と金型の忘 力解析を行った. そして，それらのスラグに関する塑 性流れを詳細に分析することで，冷間前方後方押出し における成形性とスラグ形状との関連性を明らかにす るとともに，スラグ形状が金型応力に及ぼす影響につ いて検討した. 次に，得られた結果を基にニアネット シェイプ成形が可能で，成形荷重と金型に発生する応 力のどちらも低减できる変断面形状を有するスラグ形 状を提案し，有限要素解析と鍛造機による成形実験を 行うことにより検証した.

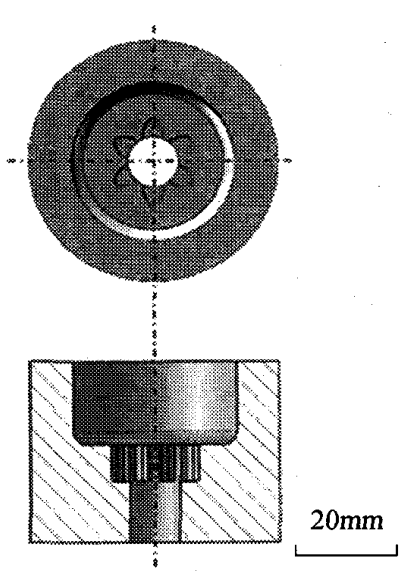

(a) Shape of the die

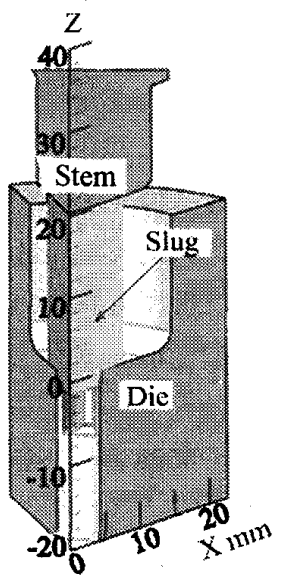

(b) FEM model
Fig. 4 Finite element model

Table 1 Computational conditions

\begin{tabular}{|l|l|l|}
\hline \multirow{3}{*}{ Slug } & $\begin{array}{l}\text { Material: S15C } \\
\text { Flow stress (MPa) }\end{array}$ & $\sigma=720.69 \varepsilon^{0.222}$ \\
\cline { 2 - 3 } & Total number of elements & 60000 \\
\hline \multirow{2}{*}{ Die } & $\begin{array}{l}\text { Material: AISI-H-13 } \\
\text { Young's Modulus(GPa) }\end{array}$ & 210 \\
\cline { 2 - 3 } & Total number of elements & 80000 \\
\hline Velocity of stem & $0.67 \mathrm{~mm} / \mathrm{s}$ \\
\hline \multicolumn{2}{|l|}{ Frictional coefficient(Shear friction law) } & 0.1 \\
\hline
\end{tabular}




\section{2. 有限要素解析}

$2 \cdot 1$ スラグ形状 スラグ形状が成形性と金型に 及ぼす影響についての知見を得るために，数種類のス ラグ形状を用いて三次元有限要素解析を行った。 図 3 は有限要素解析に用いたスラグ形状を示している.T-1 スラグおよびT-2 スラグはともに一定断面積を有し， 断面積を可能な限り小さくした形状と断面積を大きく した形状である. T-3 スラグおよび T-4 スラグは断面 積を変化させた変断面形状を有し，上下の面が T-1 ス ラグあるいは T-2 スラグとほぼ同じ断面積を持つ形状 である。

\section{2 -2 有限要素解析の方法 解析には総合加工シ} ミュレーションソフトDeform システム(米国 SFTC 社) を使用し，スラグの成形解析と金型の応力解析との連 成解析を行うことで，スラグ形状が複合ギアの成形性 と金型応力に及ぼす影響について検討した. その際に, スラグは三次元剛塑性体，金型は三次元弾性体として 定義した. 図 4 に金型形状と有限要素解析に用いたモ デルを示す. また表 1 に計算条件を示す. 有限要素計 算は簡略化のために，1/6 分割モデルを使用し，カム 部分に関しては円弧形状で近似した。

\section{3. 結果と考察}

3-1 スラグの成形性 図5はステムの押し込み 量が $6 \mathrm{~mm}$ と $9 \mathrm{~mm}$ の場合の剛塑性有限要素計算により得 られたスラグの塑性流れを示している.これらの結果 から，断面積の小さい一定断面形状を有する $\mathrm{T}-1$ スラ グの場合には，初期成形段階では主にギア部が形成さ れ，力ム部はその後に形成されている．これは，T-1 スラグは押出し比が小さいために，カム部よりギア部 の方に塑性流れが生じやすいためと考えられる.一方， 断面積の大きい一定断面形状を有する $\mathrm{T}-2$ スラグの場 合は，ギア部とカム部の両形状が同時に形成される特 徵がある.

変断面を有する T-3 スラグおよび T-4 スラグの場合 は，T-2 スラグの場合と同様にギア部とカム部が同時 に成形され，その塑性流れは T-1 スラグと T-2 スラグ の中間の様相を示している. すなわち, T-2 スラグと 比較した場合には，ギア部への塑性流動は良好である が, カム部への塑性流動は悪い。

図 6 は風塑性有限要素計算により得られた成形途中 でのスラグの変形した形状を示している. 図6の (a) および (b) は，変形したスラグを側面と下面から見た 形状を表している，この図から，成形途中ではスラグ の変形した形状が大きく異なること，およびスラグの
形状の違いによって久肉やフローマークなどの久陷の 発生の有無が異なることがわかる.このことから，適 切なスラグ形状を用いることにより，陷のない良好 な成形品を得ることが可能であると考えられる. そし て，適切なスラグ形状を見出すために，各スラグ形状 に対する塑性流れの特徴を明らかにすることが重要で あると考えられる.

(A) $\mathrm{T}-1$

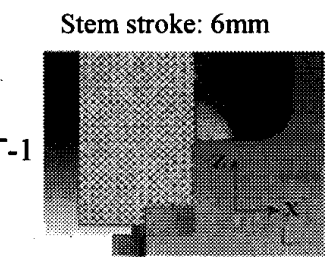

Stem stroke: $9 \mathrm{~mm}$

(B) $\mathrm{T}$
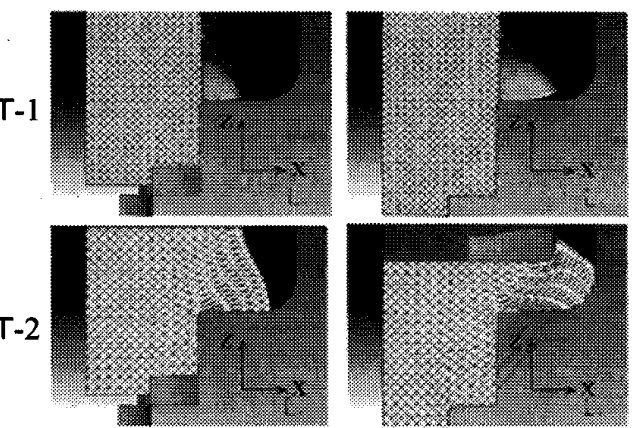

(C) $\mathrm{T}$
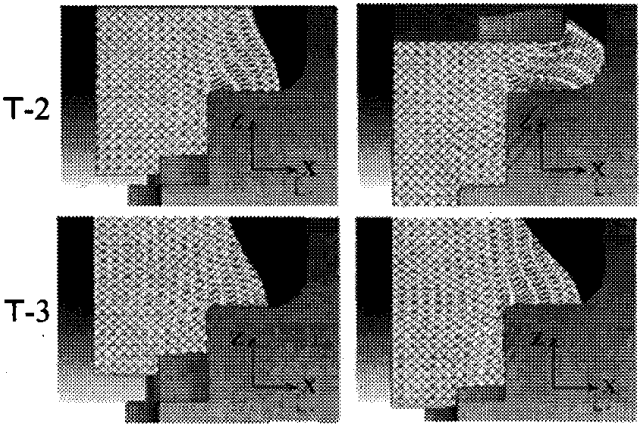

(D) $\mathrm{T}$
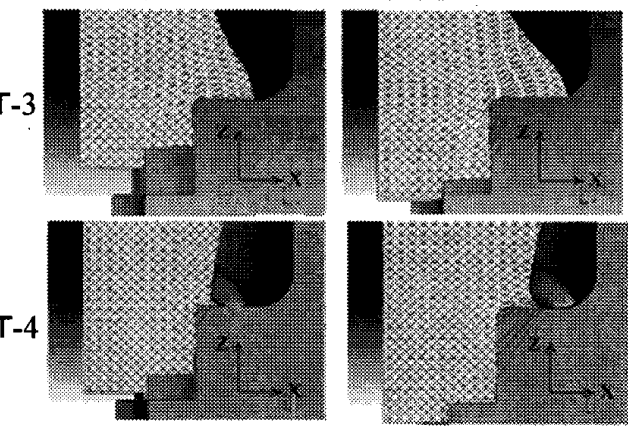

Fig. 5 Metal flow patterns of slugs obtained by FEM

(a) Side view

(b) Bottom view

(A) $\mathrm{T}-1$

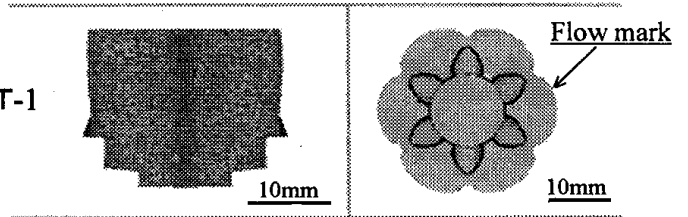

(B) $\mathrm{T}$

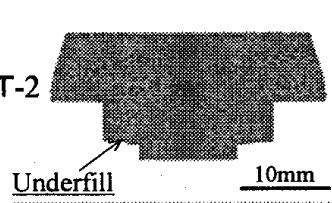

(C) $\mathrm{T}$

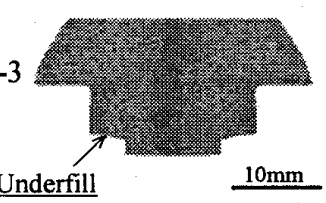

(D) T-4

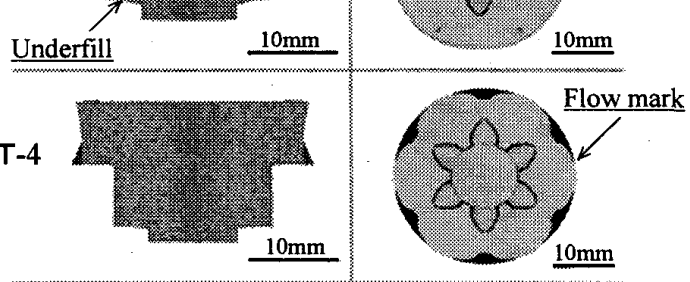

(Stem stroke: $9 \mathrm{~mm}$ )

Fig. 6 Deformed shapes of slugs 
T-3

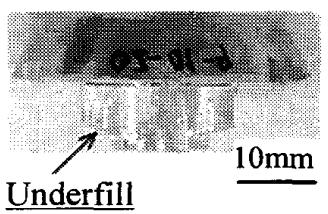

(Side view)

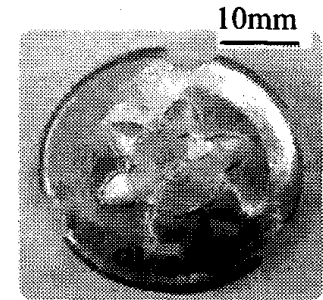

(Bottom view)

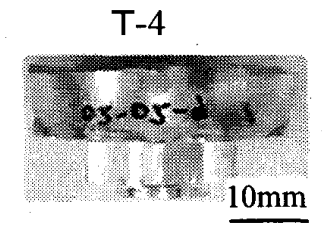

(Side view)

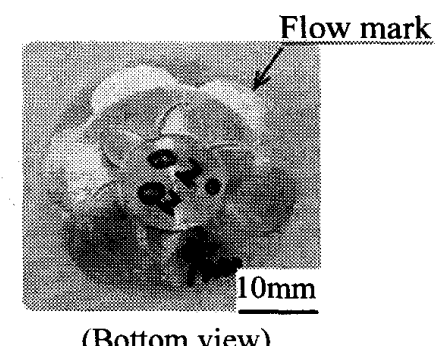

(Bottom view)

Fig. 7 Deformed shapes of T-3 slug and T-4 slug obtained by experiments using Al070 aluminum alloy

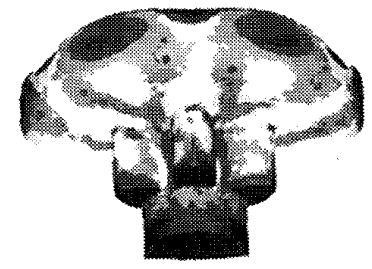

(A) $\mathrm{T}-1$

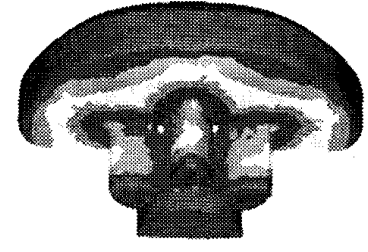

(B) $\mathrm{T}-2$

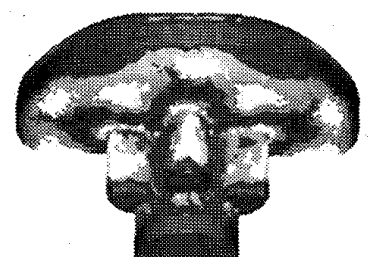

(C) $\mathrm{T}-3$

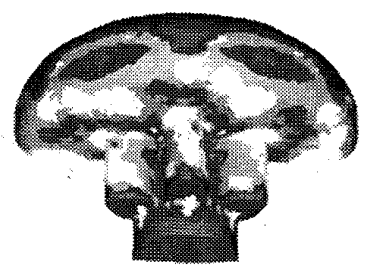

(D) $\mathrm{T}-4$

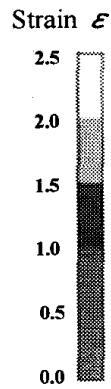

Fig. 8 Distributions of equivalent plastic strain of compound gear after forming

各スラグについて主な特徵を挙げると， T-1 スラグ およびT-4 スラグでは，カム部にフローマークが形成 されている.また, T-2 スラグおよびT-3 スラグでは, ギア先端部に欠肉が生じている.

図 7 はアルミニウム合金A1070 材からなる T-3 スラ グと T-4 スラグを用いた場合の成形実験によって得ら れた成形品の様相を示している. 図 6 と図 7 の結果の 比較から，有限要素計算により得られた成形品の形状 と成形実験により得られた成形品の形状は非常に類似 していることがわかる. そして図 7 の実験結果より， T-3 スラグではギア先端部において欠肉が発生し, T-4 スラグではカム部にフローマークが発生していること が確認できる.

以上の結果より得られた知見については，以下の通 りである.

（1）断面積の小さい一定断面形状を有する T-1 スラグ は，ギア部の成形性は良好であるが，力ム部の成形 性はフローマークが発生することから悪い．

（2）断面積の大きい一定断面形状を有する T-2 スラグ は，カム部の成形性は良好であるが，ギア部の成形 性は先端部に欠肉が発生することから悪い.これは T-1 スラグの結果と相反する結果である.

(3) 変断面形状を有する $\mathrm{T}-3$ スラグおよびT-4スラグの 塑性流れは, T-1 スラグと T-2 スラグの中間的な様 相を示す。

\section{2 成形品の塑性ひずみ 図 8 は有限要素計算} により得られた複合ギアの成形後の相当塑性ひずみ分 布を示している. 図8から，いずれのスラグを用いて も成形品の最終形状には大きな差はないが，成形品の
相当塑性ひずみ分布は大きく異なっている，具体的に は，T-1 スラグは，相当塑性ひずみ值が他と比較して 全体的に大きく，カ厶部においてひずみ分布が著しく 不均一となっている. T-1 スラグの相当塑性ひずみの 值が大きい理由は，他のスラグを用いた場合よりも成 形後の高さ減少率が大きいためと考えられる.また, カム部の不均一なひずみ分布については，フローマー クの発生によるものと考えられる.

T-2 スラグの相当塑性ひずみは, T-1 スラグと比較す ると全体的に小さく，ひずみ分布もより均一である. また T-3 スラグおよび T-4 スラグの相当塑性ひずみも T-1 スラグと比較すると全体的に小さく，ひずみ分布 もより均一になっている.

\section{3 金型応力解析 図 9 は有限要素計算により} 得られた最終成形段階における金型の最大主応力分布 を示している. 図 9 から，全てのスラグを用いた場合 において，金型のギア歯底部分とフランジ側面のコー ナ一部において高い応力が生じている，そして最大応 力は応力集中によりギア歯底部分に生じている. した がって，この部分で最も金型が損傷しやすいと考えら れる.このことは，図 2 に示す金型の損傷状況におい て，金型の割れがギア歯底部分にき裂が入ることから 生じている状況と一致している.

各スラグを用いた場合の金型のギア歯底部分での最 大主応力を比較すると，小さい断面積を有する T-1 ス ラグを用いた場合には，最大主応力は他のスラグを用 いた場合よりも高い. 一方, 大きい断面積を有する T-2 スラグを用いた場合には，最大主応力は比較的低い． また, T-3 スラグおよびT-4スラグを用いた場合には， 


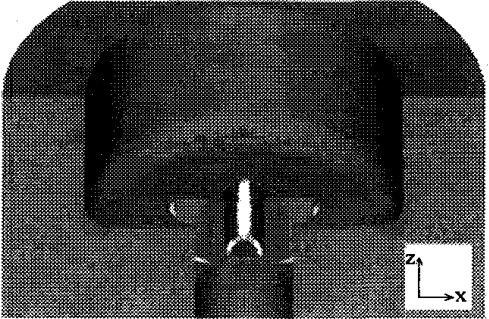

(A) T-1

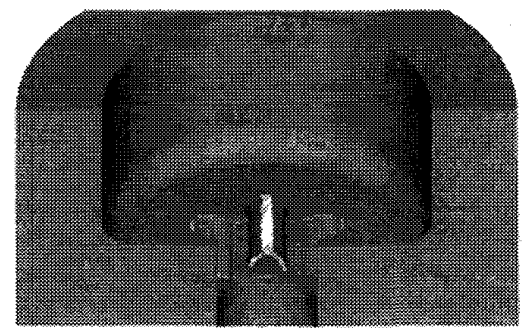

(C) T-3

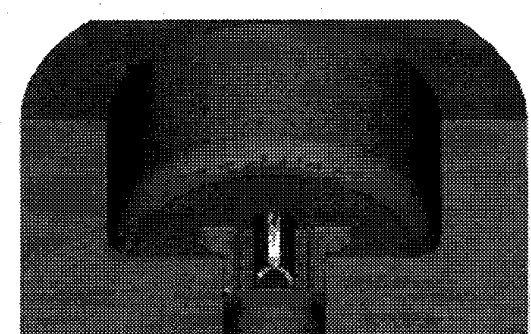

(B) T-2

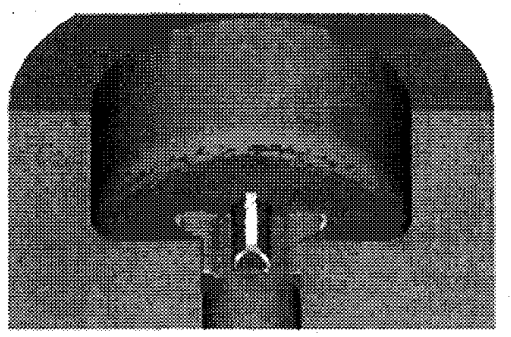

(D) T-4

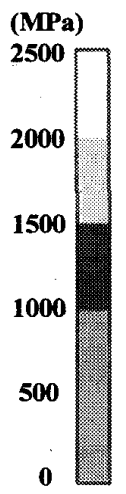

Fig. 9 Distributions of maximum stress in die at final punch stroke

ギア歯底部分の最大主応力は $\mathrm{T}-1$ スラグを用いた場合 よりも低い. さらに T-3 スラグと T-4 スラグを用いた 場合の比較では, 最大主応力は T-3 スラグの方が $\mathrm{T}-4$ スラグよりも低いという特徴がある.

3.4 スラグの取終形状と銿造機での成形これ までの結果から，断面積の小さい一定断面形状を有す る T-1のようなスラグ形状は，ギア部の成形性は良好 であるが, カム部の成形性はフローマークが発生する ことから悪くなる. また, 金型の応力も高い. 一方, 断面積の大きい一定断面形状を有する T-2 のようなス ラグ形状は，力ム部の成形性は良好で金型の応力も低 いが，ギア部の成形性は欠肉が発生することから悪く なる.このようにどちらのスラグも一長一短があるが, カム部に発生したフローマークは切削加工により容易 に除去可能であるのに対して, ギア先端の欠肉に関し ては致命的な欠陥である，そのため，ギア先端部を目 標とする製品形状と一致するように成形する必要があ る. したがって，カム部には多少のフローマークが生 じるが, ギア先端の欠肉はほとんど生じない $\mathrm{T}-4$ のよ うな変断面を有するスラグ形状が複合ギアの成形に効 果的であると考えられる.さらに，成形荷重を低减す るために，スラグの高さ減少率を小さくすることも重 要である. 以上のことから, T-4 スラグをベースとし, 側面に曲面を有すること，高さを低く抑えることを考 慮して最終的なスラグ形状を決定した.これを $\mathrm{T}-5$ ス ラグと呼び，図 10 にその形状を示す.

図 11 は S15C 材からなる T-5 スラグを用いて, 250tonf の泠間鉎造機（フォーマー）により成形した 場合の成形品の外観を示している. ギアの歯先に若干 の小さいき裂が発生しているが, 図 2 の成形品と比較
すると, 致命的な欠陷がほとんどなくなり, ギアとカ 么の成形性が大幅に改善されていることがわかる.

図 12 はT-5スラグを用いた場合の有限要素計算によ って得られた最終成形段階における金型の最大主応力 分布を表している. T-5 スラグを用いた場合の最大主 応力值は, 図 9 に示す T-1 スラグから T-4 スラグを用

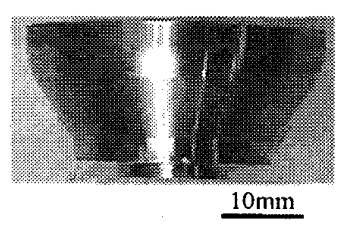

Fig. 10 Final shape of slug (T-5)

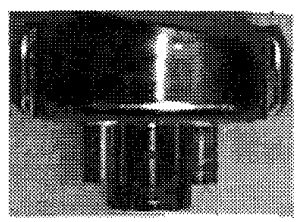

$\underline{10 \mathrm{~mm}}$

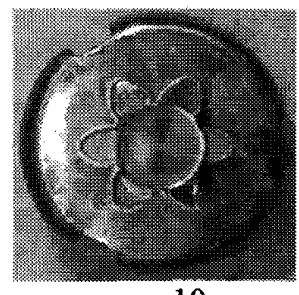

$10 \mathrm{~mm}$
Fig. 11 Aspects of product in the case where T-5 slug made of $\mathrm{S} 15 \mathrm{C}$ is used

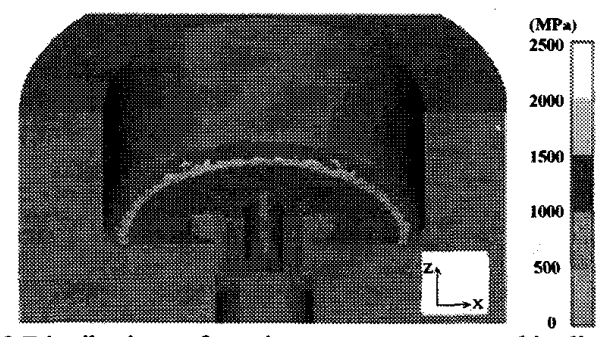

Fig. 12 Distributions of maximum stress generated in die in the case of T- 5 slug 
いた場合と比較してギア部の応力が非常に小さくなっ ていることがわかる。

図 13 は有限要素計算により得られた押出し荷重と ステム位置との関係を示している. ステム位置の $\mathrm{z}$ 方 向は図 4 に示す通りである.この図から，断面積の小 さいスラグは押出し荷重が大きい傾向にあることがわ かる.この理由は，断面積の小さいスラグほど高さ減 少率が大きいために素材の加工硬化により変形抵抗が 大きくなるためと考えられる. T-5 スラグの押出し荷 重は，他のスラグと比較して明らかに低減されている. これは，スラグの側面を曲面にしてその高さを低く抑 えた効果が現れているものと考えられる.

図 14 は有限要素計算により得られた金型内部に生 じた最大応力（最大主応力の最大值）とステム位置と の関係を示している. なお，最大応力が生じる位置は 一定ではなく,成形過程により変化している. しかし, 最終成形段階（ステムの位置が最下点の段階）では， $\mathrm{T}-5$ スラグを除いてギア歯底付近で最大の応力が生じ ている.この図から，T-1 スラグを用いた場合の金型 に発生する最大応力は成形過程を通じて常に高くなっ ている，一方， T-2 スラグを用いた場合では，最大応 力は比較的低い值となっている．T-5 スラグを用いた 場合では, 最大応力は他のスラグを用いた場合よりも 低く,金型に発生する応力は明らかに低減されている. 以上の結果から，T-5 スラグは成形性が良好であると ともに，成形荷重が小さく，金型応力も低いことがわ かった.

\section{4. 結 言}

本研究では，冷間での前方後方押出しによる複合ギ アの成形において，金型の損傷無しに良好な製品を得 ることを目的として，数種類の同一体積を有するスラ グ形状に対して，成形性と金型応力に関する三次元有 限要素解析を行った，そして，各スラグ形状に対する 塑性流れの特徵，ならびに成形品の欠陥の発生状況を 明らかにした．また同時に，スラグ形状が金型応力に 及ぼす影響を明らかにした，さらに，それらの解析結 果に基づいて，変断面形状を有するスラグ形状を提案 した．その提案したスラグに対する有限要素解析結果 と鍛造機による成形実験から，成形性が良好であるこ と，成形荷重は小さくなること，および金型応力も小 さくなることを示した．また，金型にも損傷が生じな いことを確認した.

本研究の結果から, 前方後方押出し成形において, 適切なスラグ形状を選択することにより，塑性流れを 制御してニアネットシェイプ成形ができるとともに，

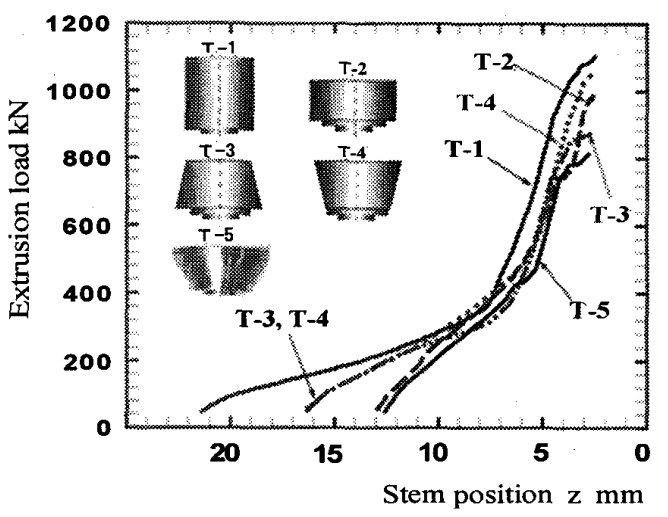

Fig. 13 Relationship between extrusion load and stem position

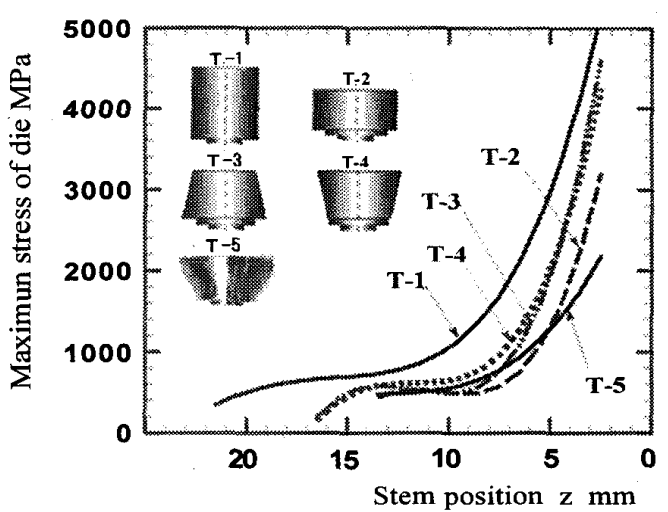

Fig. 14 Relationship between the maximum stresses generated in the die and the stem position.

成形荷重と金型に発生する応力を低减できることが明 らかになった。

本研究の一部は，九州経済産業局の「戦略的基盤技 術高度化支援事業（平成 19 年度～平成 20 年度）」に おいて，宮崎県の産学官連携により実施されたもので す.ここに記して感謝の意を表します．また研究を遂 行するにあたりご支援いただいた宮崎県産業支援財団 の長谷川誠氏，および幣島和裕氏に謝意を表します。

\section{文献}

(1) J., Saga, H., Nojima: On the Crack Initiation in A Workpiece during Forward Backward Extrusion, Journal of the JSTP, Vol.12, No.127 (1971), 611-621.

(2) The Japan Society for Technology of Plasticity: Forging Technology, (1997), p.141, Corona publishing Co., Ltd.

(3) M., Izumisawa, Effect of die and workpiece geometry on the defect formation on the tooth face of hot forged straight bevel gears-Study on hot forged straight bevel gears I-, Journal of the JSTP, Vol.16, No.178(1975), pp.1049-1056.

(4) M., Izumisawa, Effect of die and workpiece geometry on the defect formation on the tooth face of hot forged straight bevel gears -Study on hot forged straight bevel gears II-, Journal of the JSTP, Vol.17, No.180(1976), pp.14-21. 